\title{
Pro-Internationalization Policy and Outward Foreign Direct Investment
}

\author{
Miguel Matos Torres \\ Ph.D. awarded by the University of Aveiro, Portugal, October 2013
}

WHAT IS THE MECHANISM, or mechanisms, by which public support incentives influence the internationalization behavior of domestic firms? In this doctoral research I have been able to identify mechanisms through which policy operates upon firms' internationalization, and how and why policy can fail.

I found that public policy works effectively through building firms' resources and capabilities, but that it can be hijacked by opportunistic behavior, which includes "risk externalization" and the habituation (or addiction) of firms to the use of public support.

Politicians, public officials and academics who advise them believe that exports and outward foreign direct investment contribute to the economic development of their firms and their countries. Yet, the intersection of international business theory with public policy remains under-developed. This despite the widespread offering and application of public policy measures. These include incentives such as tax exemptions, reduced interest rates or even direct subsidization to encourage internationalization. Each of these is familiar the world over.

It is therefore all the more remarkable that scholars have generally neglected to investigate scientifically these mechanisms and impacts. Today, it is fair to say that we do not understand how effectively to promote outward internationalization, because we do not understand the way mechanisms work to implement policy upon firms' behavior. We can also note that there is no well articulated theory to explain why developed and developing countries should promote their firms' internationalization through exports, or through foreign direct investment. Yet the fact remains that they do promote outward internationalization, and as academics we are unable precisely to explain why.

An outcome of this deficiency is that governments lack a structured and objective rationale for pro-internationalization policies, in large part because academic research has failed to furnish them with the basis for accurate evaluation tools. Under this void, policy makers have come to rely on custom and practice in the way they design their characteristically top-down policies. Indeed, policy makers have grown reluctant to make changes to their established habit of promoting internationalization. This is because they see the relationship between policy actions and outcomes, i.e., the behavior of firms, as essentially speculative in nature, since it has not been subjected to rigorous testing to understand scientifically the mechanisms through which policies achieve their objectives.
My thesis unifies the instruments of official government intervention, mainly trade promotion, into the body of international business theory (Buckley \& Casson, 1976; Dunning, 1958; Hymer, 1960) via a novel framework within which I am able to interpret why, and how, public aid for internationalization can increase not only exports but also foreign direct investment. The thesis is divided into eight chapters. Apart from the Introduction and the Conclusion, there are two literature reviews and four empirical papers based on survey data, which questions and main findings are presented in the following sections.

\section{Why Do Firms Use Home Country Support Measures?}

The actual process that firms go through to apply for public support is: (1) they become aware of public support and (2) they make a choice to use that public support. Because this process is two staged, I apply a Heckman Selection model. I found that the greater are the internal limitations of firms and the more demanding are the conditions in which internationalization takes place, then the greater is the use made of public support. In addition to this, I also found an interesting disjoint between awareness and use. Firms' awareness of public support, while positively associated with more demanding conditions of internationalization, is unrelated to firms' lack of endowments. Aside from this, the use of public support appears to be associated with the increased inherent risk of internationalization, which, in turn, is more likely within betterendowed firms. From this, I can infer that, as public support covers the increased risk of internationalization, then it becomes more likely that firms pursue modes of entry, or select locations, with higher levels of risk, precisely because of the availability of public support.

\section{Have Firms with Foreign Direct Investment Actually Benefited from Home Country Support Measures?}

Public support may boost internationalization as intended by home country governments, but, given the possibility of opportunistic behavior on the part of firms, this fact does not necessarily align with the original policy objectives to stimulate autonomy and sustainable competencies. Comparing firms with and without foreign direct investment through a probit model, I found that firms with such investment are older, larger and more productive, but also more intensive users of public support. Therefore, firms' resources and capabilities matter in a 
much more subtle and complex way than is portrayed in the resourcebased view literature. This result agrees with my previous finding that the increased risk of internationalization is associated with the use of public support. Since this mode of entry is a higher commitment, a less liquid, and so a more risky mode of internationalization than exports, my research points to the need for a study that integrates exports and foreign direct investment to truly capture the real effects of public policy upon exports and foreign direct investment when both are being undertaken.

\section{How Do Home Country Support Measures towards Internationalization Promote Exports and Outward FDI?}

We know that the weight of evidence supports theory suggesting that exports and foreign direct investment interact strongly with each other and therefore need to be studied together. But such empirical work as there is to date has looked at the circumstantial impact of public support on exports alone (in isolation from other modes) while treating the mechanism as a black box. I use a structural equations model to investigate the impact of public support on sources of competitive advantage, and of the indirect effects of public support upon different modes of internationalization. In the initial stages of internationalization, firms use public support to reinforce their resources and capabilities, but they do not necessarily progress to export or internationalize into the more demanding conditions that can be found abroad. Firms which have enjoyed support that has upgraded their competitive advantages have subsequently become more disposed to expand into market conditions that are more challenging and risky than those they started with, and it is precisely at this point that they secure a new round of public support to fortify their resources and capabilities.

\section{How Do Firms with Foreign Direct Investment Evaluate Home Country Support Measures?}

The main obstacles that firms cite during international expansion are: (1) the lack of resources and capabilities and (2) the more demanding conditions encountered as internationalization progresses. There is public support available to meet these adversities but, as firms evolve, the probability rises that the more capable firms will seek more profitable business through modes of internationalization, or select locations that pose increasing levels of difficulty. Applying an ordered probit model to firms with foreign direct investment, I evaluate these firms' perceived importance of each type of public incentive. I found that firms with higher resources and capabilities attach less importance to public support, but that it is these same firms that tend to become intensive users of public support. It is this finding that encapsulates the tension for policy - ostensibly support measures are created to stimulate less capable firms to internationalize, but they are actually used most intensively by better endowed firms who, by their own testimony, attach less importance to support.

\section{Conclusions}

This thesis identified a dual gap in knowledge and understanding one on the part of academics and a second on the part of practitioners, and those charged with designing and implementing policy, particularly policy officials. The findings therefore naturally fill this double gap.

For academics this research has demonstrated that, when it works, public policy works through its effect on the resources and capabilities of firms. It does not work simply through subsidizing the activities of firms in the international arena. However, when public policy does not work, it is likely the outcome of being hijacked by opportunistic firms, which are already perfectly capable of successful internationalization.

These findings have import for our students. They are a copybook demonstration of the imperative to look beyond the superficial logic of custom and practice - in our study, as related to internationalization theory and the practice of policy. For research students, it is a perfect example of a research gap that has languished in plain sight for over 50 years. And for those learning the principles of international business, it provides a logical linkage between theory and the policy domainilluminating the hitherto arcane mechanism through which policy succeeds, and why policy often may fail. Students too often have been expected to swallow the staid line that policy is an inexact science.

For policy officials, the message is clear: targeting is essential. Effective selection of candidate firms that have the capacity to benefit from support is paramount. This way public money will work harder and achieve more for the welfare of domestic economies. Managers of firms in the early stages of internationalization, or considering internationalization, will glean from this research that they must employ public support as an investment in their firms' ability to internationalize; all managers of firms must avoid thinking of support as a subsidy to business as usual.

\section{References}

Buckley, P. J., \& Casson, M. 1976. The future of the multinational enterprise. London: MacMillan.

Dunning, J. H. 1958. American investment in British manufacturing industry. London: George Allen \& Unwin.

Hymer, S. H. 1960. The international operations of national firms: A study of direct foreign investment. PhD thesis, MIT, Cambridge, MA, USA.

Miguel Torres is an economist specializing in the intersection of international business with public policy. Miguel is a lecturer at the University of Aveiro, Portugal. His research centers on the use, effectiveness and impacts of public incentives intended to stimulate outward internationalization. To do this he investigates the rationale of political and policy actors who design incentives, and the resultant effects of these measures on managerial decision making. 